\title{
Perhitungan Usia Kehamilan Berdasarkan Pengukuran Tinggi Fundus Uteri dengan Hari Pertama Haid Terakhir di BPS Farida Yuliani Desa Gayaman Kecamatan Mojoanyar Kabupaten Mojokerto
}

\author{
Calculating Gestational Age Based on Fundal Height with The First Day of The Last Menstrual Period \\ at BPS Farida Yuliani, GayamanVillage, Mojoanyar Mojokerto
}

Dyah Permata Sari*

Program Studi D-III Kebidanan

Sekolah Tinggi Ilmu Kesehatan Majapahit Mojokerto, Jawa Timur

*Corresponding author : dyahpermatasari86@yahoo.co.id

\begin{abstract}
ABSTRAK
Hubungan besarnya rahim dan tuanya kehamilan penting untuk diketahui karena kemungkinan penyimpangan kehamilan seperti hamil ganda, hamil mola hidatidosa, hamil dengan hidramnion yang akan teraba lebih besar. Penelitian ini dilakukan untuk evaluasi hasil perhitungan usia kehamilan berdasarkan pengukuran tinggi fundus uteri dengan HPHT.

Penelitian ini menggunakan penelitian deskriptif, dengan desain study survey. Variabel dalam penelitian ini adalah perhitungan usia kehamilan berdasarkan pengukuran tinggi fundus uteri dengan HPHT. Populasi yang diambil semua ibu hamil trimester II dan III yang berkunjung di BPS Farida Yuliani Desa Gayaman Kecamatan Mojoanyar Kabupaten Mojokerto sejumlah 33 orang dan sampelnya sebanyak 33 orang. Teknik sampling yang digunakan adalah non probability samping dengan cara pengambilan total sampling. Penelitian ini dilaksanakan pada tanggal 4 Mei-31 Juli 2018. Pengumpulan data dengan teknik dokumentasi yang menggunakan data sekunder yaitu dari Rekam Medik dan instrument yang digunakan adalah check list. Data diolah serta disajikan dalam bentuk prosentase tabel distribusi frekuensi.

Hasil penelitian menunjukkan bahwa sebagian besar perhitungan usia kehamilan berdasarkan tinggi fundus uteri posisi lutut lurus sesuai dengan usia kehamilan berdasarkan hari pertama haid terakhir yaitu 18 responden (54.55\%).

Simpulan dalam penelitian ini adalah hasil perhitungan usia kehamilan berdasarkan pengukuran tinggi fundus uteri posisi lutut lurus sesuai dengan hari pertama haid terakhir serta ada hubungan antara gravida dengan ketepatan pengukuran tinggi fundus uteri. Diharapkan hasil penelitian dapat digunakan sebagai bahan masukan dalam memberikan asuhan kebidanan pada ibu hamil, khususnya pada saat pengukuran tinggi fundus uteri menggunakan metode pengukuran yang lebih akurat.
\end{abstract}

Kata Kunci : Usia Kehamilan, Tinggi Fundus Uteri, Hari Pertama Haid Terakhir

\section{ABSTRACT}

Relationships and parents pregnancy uterus size is important to know because of the possibility of pregnancy such as pregnancy irregularities double, hydatidiform mole pregnancy, pregnant with hydramnios which will be felt more. Therefore, this research was conducted to evaluate the results of calculation of gestational age based on height measurements with HPHTfundus.

This study used descriptive research, survey design study. The variable in this study is high fundus with HPHT. Population taken all pregnant women trimester II and III who visit the BPS Farida Yuliani Desa Gayaman Kecamatan Mojoanyar Kabupaten Mojokerto some 33 people and sample as many as 33 people. sampling technique used is next to non-probability sampling by taking total. The research was conducted on May 4 - July 31, 2018. Documentation of data collection techniques that use secondary data from the Medical Records and the instrument used is the check list. The data is processed and presented in the form of percentage frequency distribution table.

The results showed that most of the calculation of gestational age based on height fundus straight knee position according to gestational age by the first day of last period ie 18 respondents (54.55\%).

The conclusions in this study is the calculation of gestational age based on height measurements fundus knees straight line with the first day of last period and there is a relationship between gravida with high measurement accuracy 
fundus. Expected results of the study can be used as an input in providing midwifery care to pregnant women, especially during fundus height measurements using a more accurate method of measurement.

Keywords: Pregnancy, High Fundus uteri, First Day of Last Menstrual

\section{PENDAHULUAN}

Ukuran serat otot yang turut membesar menjadikan uterus semakin berat, saat hamil uterus mampu menahan beban seribu kali lebih besar. Pada akhir usia kehamilan, uterus membesar dan menekan pembuluh darah besar di dalam perut pada saat berbaring terlentang (Imelda, 2009). Hubungan besarnya rahim dan tuanya kehamilan penting untuk diketahui karena kemungkinan penyimpangan kehamilan seperti hamil ganda, hamil mola hidatidosa, hamil dengan hidaminion yang akan teraba lebih besar (Manuaba, 2010). Pengawasan antenatal mempunyai kedudukan sangat penting dalam upaya meningkatkan kesehatan mental dan fisik kehamilan, untuk menghadapi persalinan. Dengan pengawasan antenatal dapat diketahui berbagai komplikasi ibu yang dapat mempengaruhi kehamilan atau komplikasi hamil sehingga segera dapat diatasi (Manuaba, 2002).

Bayi BBLR lahir di negara berkembang. Seluruh kelahiran lebih 20 juta bayi $(15,5 \%)$ merupakan BBLR 95,6\% dari seluruh kelahiran. Menurut Ibrahim (2002) insidensi BBLR di Asia adalah 22\%. Di Indonesia, berdasarkan Survei Demografi dan Kesehatan Indonesia (SDKI) 2015-2016, angka kematian neonatal sebesar 20 per 1000 kelahiran hidup. Dalam 1 tahun, sekitar 89.000 bayi usia 1 bulan meninggal. Sebanyak 29\% kematian neonatal dikarenakan Berat badan Lahir Rendah (BBLR). Di regional Jawa Barat pertahun kelahiran BBLR sekitar 20-25\%. Sementara di level II di tingkat kabupaten di Jawa Barat sebagian besar Bayi Berat Lahir Sangat Rendah (BBLSR) dengan berat lahir kurang lebih 3. Di Propinsi Jawa Timur, BBLR masih menjadi penyebab kematian neonatal tertinggi pada tahun 2014 sebesar 36,23\% dan 2015 sebesar $34,72 \%$. Sedangkan di RSU Dr. Soetomo pada tahun 2014 dari 232 kasus kematian neonatal sebesar 78,88\% merupakan bayi dengan berat lahir rendah (BBLR) dan pada tahun 2015, $62,87 \%$ dari 307 kasus kematian neonatal merupakan BBLR, dengan infeksi sebagai penyebab kematian BBLR tertinggi sebesar 25,68\% di tahun 2014 dan 37,31\% di tahun 2015 disusul asfiksia, prematuritas, gangguan napas dan kelainan kongenital. Risiko kematian BBLR 10x lipat dibanding bayi normal. Resiko akan semakin bertambah jika bayi semakin kecil dan immature (Purwanto, 2016).

Berdasarkan data yang diperoleh dari BPS Farida Yuliani Desa Gayaman Kecamatan Mojoanyar Kabupaten Mojokerto yang melalui studi pendahuluan 30 April 2018, jumlah ibu hamil trimester II dan III sebanyak 31 orang pada tanggal 5 Februari-27 April 2018.

Berkaitan dengan panjangnya fundus uteri dapat diketemukan bahwa pada umur hamil 28 minggu panjangnya $25 \mathrm{~cm}$, umur kehamilan 32 minggu panjangnya $27 \mathrm{~cm}$, dan umur hamil 36 minggu panjangnya $30 \mathrm{~cm}$. Regangan dinding rahmi karena besarnya pertumbuhan dan perkembangan janin menyebabkan uteri makin tertarik ke atas dan menipis yang disebut segmen bawah rahim (Manuaba, 2010). Ibu hamil, masih banyak yang kurang paham bagaimana cara menghitung usia kehamilan. Hal ini sangat penting untuk mengetahui berapa umur kehamilannya. Jika ibu mengetahui umur usia kehamilannya, ibu dapat mengetahui tumbuh kembang organ janin yang dikandungnya, apa keperluan bayi di dalam kandungan, apa yang harus di berikan, serta apa saja yang harus dilakukan selama kehamilan berlangsung. Disamping itu dengan mengetahui usmur kehamilan ibu dapat mengetahui jadwal kontrol ke tenaga kesehatan. Sehingga diharapkan kehamilan dapat berjalan dengan 
sehat dan berkualitas. Menghitung HPHT hanya dapat dilkukan oleh ibu yang mempunyai siklus menstruasi teratur (28 sampai 30 hari).

Pada setiap kunjungan ibu hamil dilakukan pemeriksaan menyeluruh. Apabila hasil wawancara atau temuan pemeriksan fisik mencurigakan, dilakukan pemeriksaan lebih mendalam. TFU merupakan salah satu pemantauan dalam kehamilan. Pengukuran TFU diatas simfisis dipakai untuk mengukur kemajuan perkembangan janin dalam kandungan. Dengan TFU dapat memperkirakan umur kehamilan, dapat mengetahui resiko tinggi. TFU yang tetap atau bahkan menurun dapat mendeteksi retardasi pertumbuhan intra uteri, peningkatan yang lebih bisa saji adanya kehamilan gemeli atau hidramnion. Dengan demikian dapat disimpulkan bahwa pengukuran TFU memegang peranan penting dalam pemeriksaan kehamilan dan penting untuk dipelajari dan dikuasai seorang kebidanan (Yasmin, 2010).

\section{METODE PENELITIAN}

Jenis penelitian dalam penelitian ini menggunakan penelitian deskriptif yaitu rancangan penelitian yang bertujuan menetapkan atau menggambarkan masalah penelitian yang terjadi pada kasus atau penyakit berdasarkan distribusi tempat, waktu, umur, jenis kelamin, sosial, ekonomi, pekerjaan, status perkawinan, cara hidup dan lain-lain. (Hidayat, 2003:28). Sedangkan desain penelitian yang digunakan adalah study survey. Study survey yaitu mensurvey hasil perhitungan usia kehamilan berdasarkan posisi pengukuran TFU dan (Alimul, 2009).Variabel dalam penelitian ini adalah perhitungan usia kehamilan berdasarkan pengukuran tinggi fundus uteri dengan hari pertama haid terakhir. Populasi dalam penelitian ini adalah semua ibu hamil trimester II dan III yang berkunjung di BPS Farida Yuliani Desa Gayaman Kecamatan Mojoanyar Kabupaten Mojokerto pada tanggal
4 Mei - 31 Juli 2018. Sampel adalah bagian populasi yang akan diteliti atau sebagian jumlah dari karakteristik yang dimiliki oleh populasi (Alimul, 2009). Sampel yang digunakan dalam penelitian ini adalah semua ibu hamil trimester II dan III yang berkunjung di BPS Farida Yuliani Desa Gayaman Kecamatan Mojoanyar Kabupaten Mojokerto pada tanggal 4 Mei - 31 Juli 2018. Teknik sampling, yang digunakan dalam penelitian ini adalah non propability sampling dengan metode total sampling (sampling jenuh) yaitu pemilihan yang teknik penentuan sampelnya bila semua anggota populasi digunakan sebagai sampel (Sugiyono, 2007).

\section{HASIL DAN PEMBAHASAN HASIL PENELITIAN}

\section{Data Umum}

a.Karakteristik Responden Berdasarkan Pendidikan

Berdasarkan Tabel 1 menunjukkan bahwa sebagian besar responden berpendidikan SMU yaitu 22 responden $(66.67 \%)$

b.Karakteristik Responden Berdasarkan Pekerjaan

Berdasarkan Tabel 2 menunjukkan bahwa hampir seluruh dari responden tidak bekerja yaitu 31 responden $(93.94 \%)$

c. Karakteristik responden Berdasarkan Usia ibu

Berdasarkan Tabel 3 menunjukkan bahwa hampir seluruh dari responden berusia antara 20-35 tahun yaitu 26 responden $(78.79 \%)$

d. Karakteristik Responden Berdasarkan

Gravida

Berdasarkan Tabel 4 menunjukkan bahwa sebagian besar responden merupakan Primigravida yaitu 17 responden (51.52\%)

\section{Data Khusus}

Hasil perhitungan usia kehamilan berdasarkan TFU (Tinggi Fundus Uteri) dibandingkan HPHT (Hari Pertama Haid Terakhir). 
Tabel. 1 Distribusi Frekuensi Responden Berdasarkan Pendidikan

\begin{tabular}{|c|c|c|c|}
\hline No & Pendidikan & Jumlah & $\begin{array}{c}\text { Frekuensi } \\
(\%)\end{array}$ \\
\hline 1 & SD & 1 & 3,03 \\
\hline 2 & SMP & 8 & 24,24 \\
\hline 3 & SMU & 22 & 66,67 \\
\hline 4 & $\mathrm{PT}$ & 2 & 6,06 \\
\hline & Total & 33 & 100 \\
\hline
\end{tabular}

Tabel. 2 Distribusi Frekuensi Responden Berdasarkan Pekerjaan

\begin{tabular}{|c|l|c|c|}
\hline No & Pekerjaan & Jumlah & $\begin{array}{c}\text { Frekuensi } \\
(\%)\end{array}$ \\
\hline 1 & Bekerja & 2 & 6.06 \\
\hline 2 & $\begin{array}{l}\text { Tidak } \\
\text { Bekerja }\end{array}$ & 31 & 93.94 \\
\hline & Total & 33 & 100 \\
\hline
\end{tabular}

Tabel 3 Distribusi Frekuensi Responden Berdasarkan Usia Ibu

\begin{tabular}{|c|c|c|c|}
\hline No & Usia & Jumlah & $\begin{array}{c}\text { Frekuensi } \\
(\%)\end{array}$ \\
\hline 1 & $<20$ th & 7 & 21.21 \\
\hline 2 & $20-35$ th & 26 & 78.79 \\
\hline 3 & $>35$ th & 0 & 0 \\
\hline & Total & 33 & 100 \\
\hline
\end{tabular}

Tabel 4 Distribusi Frekuensi Responden Berdasarkan Kehamilan

\begin{tabular}{|c|l|c|c|}
\hline No & \multicolumn{1}{|c|}{ Gravida } & Jumlah & $\begin{array}{c}\text { Frekuensi } \\
(\mathbf{\%})\end{array}$ \\
\hline 1 & Primi & 17 & 51,52 \\
\hline 2 & Multi & 16 & 48,48 \\
\hline & Total & 33 & 100 \\
\hline
\end{tabular}

Tabel 5 Distribusi Frekuensi Usia Kehamilan Berdasarkan TFU Dengan Hari Pertama Haid Terakhir

\begin{tabular}{|c|l|c|c|}
\hline No & $\begin{array}{c}\text { Pengukuran } \\
\text { TFU }\end{array}$ & Jumlah & $\begin{array}{c}\text { Frekuensi } \\
(\mathbf{\%})\end{array}$ \\
\hline 1 & Tepat & 18 & 54,55 \\
\hline 2 & Tidak tepat & 15 & 45,45 \\
\hline & Total & 33 & 100 \\
\hline
\end{tabular}

Berdasarkan Tabel 5 menunjukkan bahwa sebagian besar perhitungan usia kehamilan berdasarkan TFU sesuai dengan usia kehamilan berdasarkan HPHT yaitu 18 responden (54.55\%).

\section{PEMBAHASAN}

Berdasarkan Tabel 4 menunjukkan bahwa sebagian besar responden merupakan Primi gravida yaitu 17 responden $(51.52 \%)$ dan berdasarkan Tabel 5 menunjukkan bahwa sebagian besar perhitungan usia kehamilan berdasarkan TFU sesuai dengan usia kehamilan berdasarkan HPHT yaitu 18 responden $(54.55 \%)$.

Menurut Yasmin (2010) bahwa pengukuran tinggi fundus uteri terdapat 4 metode yang masing-masing memiliki kelemahan dan 
kelebihan, dimana metode 3 yang paling sering dilakukan merupakan metode yang akurat kedua dalam pengukuran TFU setelah usia kehamilan 22-24 minggu. Sementara itu pengukuran dengan metode 4 di mana menggunakan pita ukur sama seperti metode ke-3 tetapi bila fundus telah mencapai ketinggian sama dengan umbilicus (22 minggu), tambahkan $6 \mathrm{~cm}$ pada jumlah yang terukur.

Pengukuran TFU yang dilakukan dalam penelitian ini menggunakan pita pengukur yang mungkin merupakan metode akurat kedua dalam pengukuran TFU dimana cara ini efektif pada usia kehamilan 22-24 minggu tanpa menambah jumlah yang terukur seperti pada metode 4. Hal ini menghasilkan jumlah pengukuran yang agak jauh berbeda dengan usia kehamilan berdasarkan HPHT.

Hasil tabulasi silang antara gravida dengan ketepatan pengukuran TFU pada ibu primigravida didapatkan hampir seluruh hasil pengukuran usia kehamilan berdasarkan TFU sesuai dengan HPHT yaitu 11 responden (64.71\%) dan pada ibu multigravida didapatkan sebagian besar tidak sesuai dengan HPHT yaitu 9 responden $(56.25 \%)$.

Menurut Manuaba (2010) bahwa memper- gunakan tinggi fundus uteri untuk memperkirakan usia kehamilan terutama tepat pada hamil pertama. Pada kehamilan primi luas panggul wanita relative lebih kecil dibandingkan setelah wanita itu melahirkan, selain itu pengukuran TFU bersifat subyektif sehingga hasilnya akan berbeda pada tiap-tiap individu pengukur.

\section{KESIMPULAN}

Hasil penelitian menunjukkan bahwa sebagian besar perhitungan usia kehamilan berdasarkan TFU sesuai dengan usia kehamilan berdasarkan HPHT yaitu 18 responden (54.55\%).

\section{DAFTAR PUSTAKA}

Alimul, Aziz. 2009. Metode Penelitian Kebidanan dan Teknik Analisa Data. Jakarta: Rineka Cipta.

Ani. 2010. Cara Menghitung Usia Kehamilan. Jakarta : Alfa Beta.

Imelda. 2009. Panduan Kehamilan dan Perawatan Bayi. Victory. Jakarta.

Manuaba. 2002. Ilmu Kebidanan, Penyakit Kandungan Dan Keluarga Berencana Untuk Pendidikan Bidan. Jakarta. EGC.

Manuaba. 2010. Ilmu Kebidanan, Penyakit Kandungan Dan Keluarga Berencana Untuk Pendidikan Bidan. Jakarta. EGC.

Purwanto, N. 2016. Psikologi Pendidikan. Bandung : PT. Remaja Rosdakarya.

Sugiyono. 2007. Statistik Untuk Penelitian. Jakarta : Alfa Beta.

Yasmin. 2010. Pengukuran Tinggi Fundus Uterus. Jakarta : Alfa Beta. 